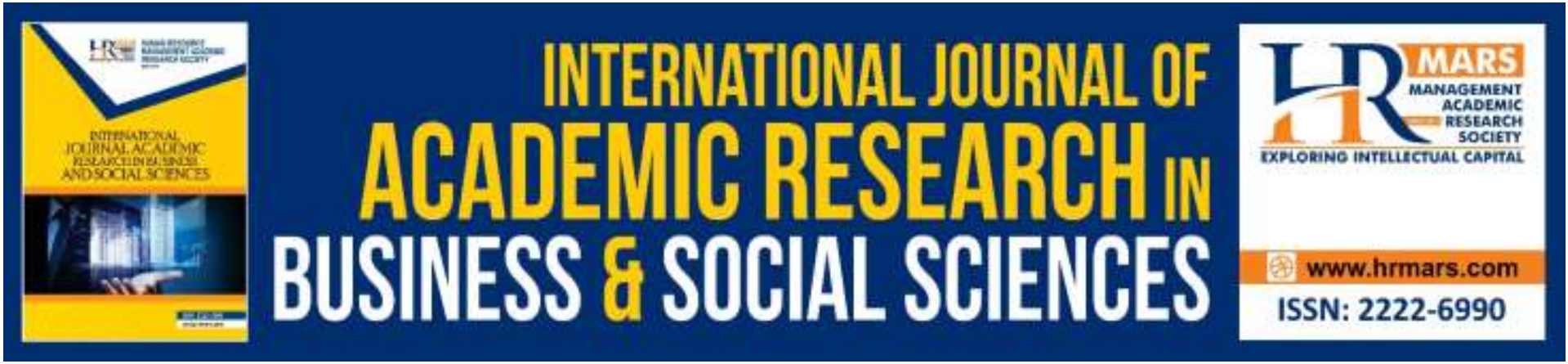

\title{
Critical Review on Food Security in Malaysia for Broiler Industry
}

\section{Syarliza llyana Sansul Bahri, Ahmad Shabudin Ariffin, Shahimi Mohtar}

To Link this Article: http://dx.doi.org/10.6007/IJARBSS/v9-i7/6186

DOI: $10.6007 /$ IJARBSS/v9-i7/6186

Received: 12 May 2019, Revised: 27 June 2019, Accepted: 30 June 2019

Published Online: 23 July 2019

In-Text Citation: (Bahri, Ariffin, \& Mohtar, 2019)

To Cite this Article: Bahri, S. I. S., Ariffin, A. S., \& Mohtar, S. (2019). Critical Review on Food Security in Malaysia for Broiler Industry. International Journal of Academic Research in Business and Social Sciences, 9(7), 869876.

Copyright: (C) 2019 The Author(s)

Published by Human Resource Management Academic Research Society (www.hrmars.com)

This article is published under the Creative Commons Attribution (CC BY 4.0) license. Anyone may reproduce, distribute, translate and create derivative works of this article (for both commercial and non-commercial purposes), subject to full attribution to the original publication and authors. The full terms of this license may be seen at: http://creativecommons.org/licences/by/4.0/legalcode

\section{Vol. 9, No. 7, 2019, Pg. 869 - 876}

Full Terms \& Conditions of access and use can be found at http://hrmars.com/index.php/pages/detail/publication-ethics 


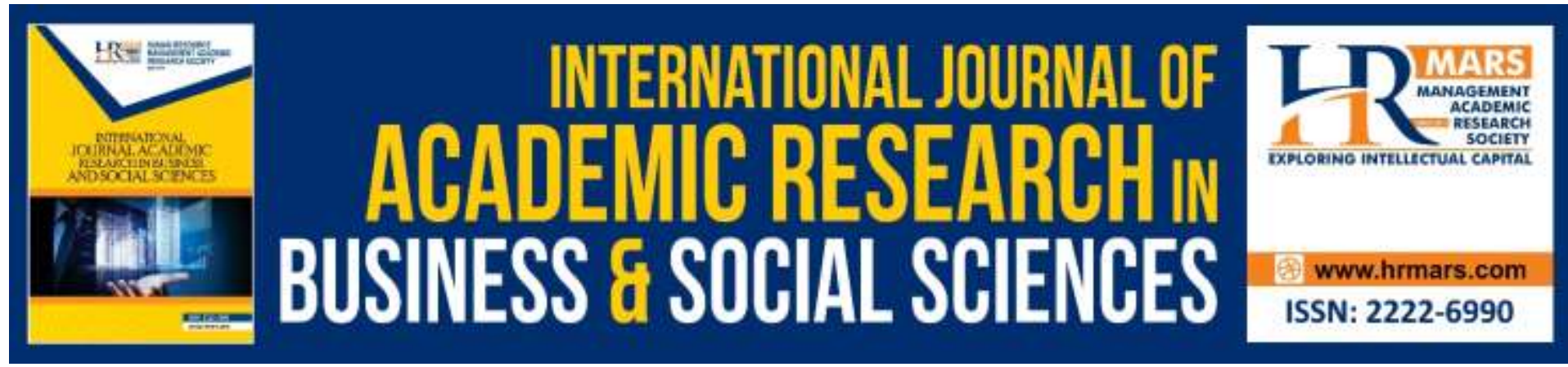

\title{
Critical Review on Food Security in Malaysia for Broiler Industry
}

\author{
Syarliza llyana Sansul Bahri ${ }^{1}$, Ahmad Shabudin Ariffin², \\ Shahimi Mohtar ${ }^{3}$ \\ ${ }^{1,3}$ School of Technology Management and Logistics, Universiti Utara Malaysia, Malaysia, \\ ${ }^{2}$ Faculty of Muamalah Management, Perlis Islamic University and College \\ Email: syarlizailyana@gmail.com
}

\begin{abstract}
Broiler industry is one of the important industry in the world. The producer around the world concerned about the industry growth. Broiler meat production in Asia is expected to rise due to the increasing in consumption. Malaysia also showed the same scenario. The industry became one of the important industry which is it able to contribute to Malaysian GDP. Besides, it be a staple food in Malaysia since it is the cheapest and safe source of meat and protein. Therefore, the production of broiler meat also expected to increase every year and the demand is expected to increase until the year 2020. The industry has capability and able to grow further to fulfil the demand. However, broiler producer is facing with various challenging issues in the changing and uncertainty environment which can increase risk to sustain and maintain the performance of farm that can affect food security in Malaysia. This paper will highlight the effect of food insecurity for Malaysia and the connection with technology.
\end{abstract}

Keywords: Food Security, Broiler Industry, Technology.

\section{Introduction}

Broiler industry become one of the important industry in the world. Based on Conway (2018), total production of world broiler meat is estimated to have modest production growth at 120.5 million metric tons in 2017 and 122.5 million tons in 2018, representing a 1.6 percent change from 2017 to 2018 . Moreover, world broiler meat production also in uptrend. The production for 2016 is nearly 116 million metric tons and it is estimated to rise driven by world population that estimated to be 8.14 billion by 2025 .

In Malaysia, broiler become the most important livestock industry and the meat has become the staple food for Malaysian. According to Department Veterinary Services (2018), the production of broiler meat in Malaysia is 1707.6 million metric tons in year 2018 compared to 2017 which is 1664.9 million metric tons. The consumption of broiler meat in Malaysia also increase approximately 45.6 million metric tons change from year 2017 to 2018. In addition, per capita consumption of broiler also rise from 50.1 in 2017 to $51 \mathrm{~kg}$ in 2018. 
While, self-sufficient for broiler is about 103.40 for 2018 . Based on all the data, it can be concluded that the industry has a bright future and able to grow bigger even though it is facing challenges. Heavily dependence on imported grain that used to feed the broiler, increase in cost, climate change, and food security are some of the challenges that not good for business and they have global impact as well.

\section{Broiler Industry}

Broiler industry is one of the important sector in Malaysia. Among all livestock products sold in Peninsular Malaysia, broiler meat is the main type that is consumed by Malaysian for cultural and religious reasons ("Asia accounts for a third", 2015). Malaysian broiler industry has been achieved self-sufficiency ratio since 1984. The industry is exposed to many factors that can affect the profit and loss account and viability of the farmers such as heavy dependence on imported raw material for animal feed which is the price usually instable (Elsedig, Mohd \& Fatimah, 2015). Elsedig, Mohd \& Fatimah (2015) also stated that more than $65 \%$ of the broiler production cost are for chicken feed production. This is due to the usage of approximately four million tons of imported soybean and corn compound feed annually to feed the broiler. Both ingredients are imported from Argentina and the price are not fixed according to the world demand and it will effect on chicken price. Article "Malaysian Poultry Industry Meeting" (2016) said that there are three factors why the production cost in broiler production is rising year by year. First factor is a reduction in fuel subsidies. With the increasing price in fuel, the raw material for chicken feed will be increase too. Besides that, the implementation of minimum wages for farmers also affect the production cost. Lastly, depreciation of Ringgit Malaysia also contributed to the increasing in production cost. Therefore, Malaysian needs to improve its ability to produce chicken feed themselves using technology optimally and not rely on other countries.

Table 1 shows broiler population in Peninsular of Malaysia by state for 2017. Based on the table, the total broiler population in Peninsular Malaysia for 2017 is 163,631,796. In addition, the highest broiler population is coming from Johor and least is from Perlis. 
Table 1. Broiler population in Peninsular Malaysia for 2017

\begin{tabular}{|l|c|}
\hline \multicolumn{1}{|c|}{ State } & $\mathbf{2 0 1 7}$ \\
\hline Perlis & $\mathbf{1 , 5 6 2 , 0 0 0}$ \\
\hline Kedah & $38,494,700$ \\
\hline Pulau Pinang & $5,807,600$ \\
\hline Perak & $25,341,211$ \\
\hline Selangor & $11,140,595$ \\
\hline Negeri Sembilan & $13,086,713$ \\
\hline Melaka & $6,807,601$ \\
\hline Johor & $45,957,800$ \\
\hline Pahang & $9,755,526$ \\
\hline Terengganu & $\mathbf{2 , 4 9 2 , 8 0 0}$ \\
\hline Kelantan & $\mathbf{2 , 5 8 5 , 2 5 0}$ \\
\hline W.P Kuala Lumpur & 0 \\
\hline Total population & $\mathbf{1 6 3 , 6 3 1 , 7 9 6}$ \\
\hline
\end{tabular}

Source: Malaysia Department of Veterinary Services, 2017

Broiler industry in Malaysia is divided into two categories of farms, namely conventional farm and commercial farm. Conventional farm can be define as a farm that belong to independent entrepreneurs. While, commercial farm run business on contract farming basis that have cooperation between integrator and farmer. Malaysian production of broiler usually practice contract farming system to produce broiler meat. There are a lot of contract farming definitions. Generally, contract farming refers a contractual arrangement between a farmer and a firm. The agreement is whether oral or written, which is provides resources and or specifies one or more conditions of production. In addition to one or more marketing conditions, for an agricultural product, which is non-transferable to a situation in which a farmer grow an agricultural product for a vertically integrated corporation (Rehber, 2007). Contract farming also can be define as a farmer (grower) will grow or raise an agricultural product for a vertically integrated corporation (integrator) with a contract that have the direction of the business (Baluch, Arifin \& Abas, 2017). Basically, contract farming consist of two parties which is grower and integrator. Grower have to maintain the broiler farm that is on their land. They also have to harvest and delivers amount of chicken. Meanwhile, integrator have responsible to provide all the equipment and inputs for the growers.

The purpose of contract farming are for survivability, sustainability and to enhance income to small poultry farmers. All inputs for the industry are written in the contracts. Some of the provisions that stated on the contract are market provision, resource provision, and management specification. Market provision is all about the term and condition between grower and integrator for the future sale and purchase of a livestock product. While, resource provision is an agreement that integrator agrees to provide certain inputs including times, land preparation and technical advice. Lastly, management specification stated the grower agrees to abide by proposed production methods, input regimes, cultivation and harvesting specification (Bijman, 2008). 


\section{Integrator}

Basically, integrator in broiler industry is define as a company who have responsible for providing all essential input to the grower such as chicks and medication. In Malaysia, there were four grandparent stock farms in year 2017 that supply 100 percent of the parent stock chicks needed by the parent stock farms. In addition, there are 20 parent stock farm companies in the Peninsular of Malaysia. All these farms produced more than 807.52 million broiler day-old-chicks in 2017. Predominant breeds are Cobbs and Ross that approximately 92 percent consumption and other breeds are Arbor Acres and Indian River. For average, there are 2606 broiler grower farms that producing 767 million birds every year. About 52.71 million live birds and 15.01 thousand tons of chicken meat and further processed products were exported, mostly to Singapore. There are 23 broiler parent stock companies of which ten 10 are integrators and 13 are non-integrators with a total of 79 farms are in operation in the year 2012. Table 2 shows list of some of the integrator in Malaysia.

Table 2. List of integrators in Malaysia

\begin{tabular}{|l|l|}
\hline No. & \multicolumn{1}{|c|}{ Integrators } \\
\hline 1. & Ayamas Integrated Poultry Industry Sdn Bhd \\
\hline 2. & Leoung Hup Agrobusiness Sdn Bhd \\
\hline 3. & Charoen Pokphand Jaya Farm Sdn Bhd \\
\hline 4. & HLRB Broiler Farm Sdn Bhd \\
\hline 5. & CAB Cakaran Southern Sdn Bhd \\
\hline 6. & Dindings Poultry Development Centre Sdn Bhd \\
\hline 7. & DBE Poultry Sdn Bhd \\
\hline 8. & Goldform Corporation Sdn Bhd \\
\hline
\end{tabular}

Source: Malaysia Department of Veterinary Services, 2017

\section{Food Security}

One of the challenges that broiler industry have to face is food security. Since the beginning of the twentieth century, the human population has growing more year by year. This growth has put huge pressure on the world food production capacity. With the increase of world population, food security is a great concern issue not only in the developed country but more so in the developing country including Malaysia (Samsudin, Sharaai, \& Ismail, 2015). The development and improvement of the industry will ensure the food security in the country and reduces dependency on imported food. There are a lot of food security definitions. According to Bello (2005), food security is an availability of sufficient food per capita and capability to access sufficient food for every individual in the country. While, definition from Food and Agriculture Organization (FAO) describe food security as a situation where the population has, at any time, social, economic and physical access to an acceptable quantity along with a quality of food to meet up every day peoples requirements and food favorites (FAO, 2003).

The importance of food security in Malaysia is to make sure that Malaysian have enough foods if there is any unexpected things is happening to the country. For instance, what will happen if the imported country is refuse to import food to Malaysia anymore probably because of anything bad happen to the imported country, incapability of our government to pay for it, 
or depreciation of Ringgit Malaysia? (Shahidan \& Othman, 2018). Of course, Malaysia will face a very dangerous situation where the food supply from domestic is not enough. Luckily, Malaysia becomes self-sufficient in poultry meat production, which include chicken, ducks and quails. The total production of meat is capable to meet the domestic demand in Malaysia. Although Malaysia has become self-sufficient in broiler meat production, food security still be the serious concerns regarding the long-term sustainability of intensive farming system (Samsuddin, Sharaai \& Ismail, 2015).

Broiler is the second staple food in Malaysia after rice, that can provides a necessary protein source for Malaysian. In addition, the price of broiler is cheaper than the other meat like pork and beef. Therefore, rice and broiler meat are the most significant staples food to Malaysian. Meanwhile, the Malaysian population will increase every day. As the population grows, it is crucial to consider the long-term impacts on the environment in line with the broiler availability for domestic consumption of Malaysian at a reasonable price. Besides, it is important to guarantee sustainable production of broiler for present and future generation. Based on Ahmed and Siwar (2013), there are three issues of food security. First issue is a rising demand for food commodities. This is due to expected increase in population for coming next few decades that will multiply the demand of food. Secondly, changes in the type of food that people consume has high probability. The increasing of people's per capita income also will give effect on the type and nature of food that will produced. Lastly, the price of the food will rise due to increase in price of food commodities in global (Ahmed \& Siwar, 2013).

\section{Technology and Food Security}

Based on Samsuddin, Sharaai \& Ismail (2015), there are two reasons that affect to the broiler accessibility for Malaysian. First, the increasing in cost of living. Secondly, the increase in broiler meat price due to the rise in broiler production costs. This article stress more on the increasing broiler production cost so that broiler production will sustainable in maintaining cheaper source of protein among Malaysian. As stated before, heavy dependence on imported grain to feed the broiler will affect the sustainability of broiler industry and consequently can affect food security itself (Elsedig, Mohd \& Fatimah, 2015). The emerging technologies in science, technology and innovation can give great impacts on the future of food security. Technology also have ability in reducing the impact of natural resource constraints. For instance, provide food for the hungry people, land and water issue, and can reducing crisis among people like starvation in many poor countries. (Shahidan \& Othman, 2018).

In the context of Malaysian broiler industry, the employment of technology has been widespread. Samsudin (2013) stated that, technology and R\&D in feed production, can improve surveillance for disease free broiler production for a good agricultural practices. Malaysia plans to increase its broiler production to 1.49 million metric tons in 2020 . Therefore, changes production of broiler is identified by Malaysian Government can be an effective solution to meet higher demand of broiler meat in the future. In addition, technologies is very useful to address and prevent major broiler welfare issues. It also can provide farmers with faster answers in management that would effect in economic and efficiency (Sassi, Averós \& Estevez, 2016). 


\section{Conclusion}

Broiler meat is important to Malaysian as it is included in their diets at least once a week. It is the most competitive industry in the poultry sub-sector. The development and sustainability of broiler industry in Malaysia be the crucial issues. Food security also be an important issue to discuss. The application of technologies in the production system enables the industry to be developed efficiently and consequently can affect to the food security in Malaysia.

\section{Corresponding Author}

Syarliza llyana Sansul Bahri

School of Technology Management and Logistics

Universiti Utara Malaysia, Malaysia

Email: syarlizailyana@gmail.com

\section{References}

Ahmed, F., \& Siwar, C. (2013). Food intake and nutritional status among adults: sharing the Malaysian experience. Pakistan Journal of Nutrition, 12(11), 1008-1012.

Asia accounts for a third of chicken meat output. (8 October 2015). The Poultry Site. Retrieved from http://www.thepoultrysite.com/articles/3533/global-poultry-trends-asiaaccounts-for-a-third-of-chicken-meat-output/

Baluch, S. M. N., Ariffin, A. S. \& Abas, Z. (2017). Servitization in Malaysian Poultry Contract Farming: A Critical Overview. International Journal of Supply Chain Management, 6 (1), 259-264.

Bello, A. L. (2005). Ensuring Food Security - A Case for ASEAN Integration. Asian Journal of Agriculture \& Development, 2(1\&2), 87-108.

Bijman, J. (2008). Contract farming in developing countries. Wageningen University, Netherlands.

Conway, A. (2018, 6 June). World poultry production at nearly 123 million tons in 2018. Poultry Trends. Retrieved from http://www.poultrytrends.com/2018/index.php

Department of Statistics Malaysia. (2018, 12 April). Selected Agricultural Indicators. Retrieved from https://www.dosm.gov.my/v1/index.php?r=column/cthemeByCat\&cat=72\&bul_i d=UjYxeDNkZ0xOUjhFeHpna20wUUJOUT09\&menu_id=ZOVTZGU1UHBUT1VJMFIpaXRR R0xpdz09

Department of Veterinary Services Malaysia. (2018). Perangkaan Ternakan 2017-2018. Retrieved from http://www.dvs.gov.my/dvs/resources/user_1/2019/BP/Perangkaan\%20Ternakan/3._ Msia_Perangkaan_ternakan_M_Surat_1-15_.pdf

Department of Veterinary Services Malaysia. (2017). Broiler population by state. Retrieved from http://www.dvs.gov.my/dvs/resources/user_1/2019/BP/Perangkaan\%20Ternakan/6._S em_._Msia_Populasi_ternakan_M_Surat_20-33_.pdf

Elsedig, E. A. A., Mohd, M. I., \& Fatimah, M. A. (2015). Assessing the competitiveness and comparative advantage of poultry production in Johor using policy analysis matrix. International Food Research Journal, 22(1), 116-121.

Food and Agriculture Organization. (2003). Food security: concepts and measurement. Retrieved from http://www.fao.org/docrep/005/y4671e/y4671e06.htm 
Malaysian Poultry Industry Meeting Domestic Demand. (9 March 2016). Poultry World. Retrived from http://www.worldpoultry.net/Meat/Articles/2014/3/Malaysian-poultry-industry-

Rehber, E. (2007). Contract Farming: Theory and Practice, ICFAI University Press, Hyderabad, India.

Samsuddin, N. S., Sharaai, A. H. \& Ismail, M. M. (2015). Sustainability of chicken meat production in achieving food security in Malaysia. Advances of Environmental Biology, 9(23), 1-6

Sassi, N. B., Averós, X., \& Estevez, I. (2016). Technology and Poultry Welfare. Animals, 6(10), 62; https://doi.org/10.3390/ani6100062

Shahidan, N. S. \& Othman, N. A. (2018). A Review on Technology Utilization of Malaysian Broiler Industry in Enhancing Food Security. Journal of Computational and Theoretical Nanoscience 24(12):9419-9422.

Shamsudin, M. N. (2013). Food security and policy responses with special reference to the poultry industry. Proceeding of WPSA (Malaysia Branch) and WVPA (Malaysia Branch) Scientific Conference 2013. 